\title{
Modeling and Simulation of Fuzzy Logic based Maximum Power Point Tracking (MPPT) for PV Application
}

\author{
Ahmad Saudi Samosir, Herri Gusmedi, Sri Purwiyanti, Endah Komalasari \\ Departement of Electrical Engineering, University of Lampung, Bandar Lampung, Indonesia
}

\begin{tabular}{l}
\hline \hline Article Info \\
\hline Article history: \\
Received Sep 30, 2017 \\
Revised Jan 3, 2018 \\
Accepted Feb 1, 2018 \\
\hline
\end{tabular}

Keyword:

Fuzzy logic algorithm

Maximum power point tracking MPPT

Photovoltaic

Simulink

\begin{abstract}
This paper presents modeling and simulation of maximum power point tracking (MPPT) used in solar PV power systems. The Fuzzy logic algorithm is used to minimize the error between the actual power and the estimated maximum power. The simulation model was developed and tested to investigate the effectiveness of the proposed MPPT controller. MATLAB Simulink was employed for simulation studies. The proposed system was simulated and tested successfully on a photovoltaic solar panel model. The Fuzzy logic algorithm succesfully tracking the MPPs and performs precise control under rapidly changing atmospheric conditions. Simulation results indicate the feasibility and improved functionality of the system.
\end{abstract}

Copyright $\odot 2018$ Institute of Advanced Engineering and Science. All rights reserved.

\section{Corresponding Author:}

Ahmad Saudi Samosir,

Departement of Electrical Engineering,

University of Lampung,

No. 1, Jln. Prof. Soemantri Brojonegoro, Bandar Lampung, 35152, Indonesia.

Email: ahmad.saudi@eng.unila.ac.id

\section{INTRODUCTION}

The growing energy demand of the world and the tremendous risk of climate change associated with the use of fossil fuels have driven research and development of alternative energy sources that are clean, efficient, renewable and environmentally friendly. Among all renewable energy sources, solar power systems attract more attention because they have several advantages such as pollution-free, low maintenance costs and low operating costs. Their sources of energy, which is derived from solar energy, are also widely available and it is free [1]-[4].

In solar power system, the solar energy is directly converted into electrical energy by solar PV module. The main components of solar PV systems are solar cells made from semiconductor materials that have a photovoltaic effect, which serves to convert solar energy into direct current electricity. When exposed to sunlight; the solar panels will generate the direct current electricity, which is ready to supply power to the load.

Solar Panels do not need much maintenance and have no moving parts. The unfavorable issue with solar PV systems is the high installing cost and the variation of energy form the solar panel with environmental conditions. In order to attain the maximum efficiency from the solar panel, it is important to obtain the maximum available power at any operating condition [5]. Also, the power distribution across the system has to be managed. Storage devices are used so that the energy is stored or supplied according to the availability of sufficient power and the load requirements [6].

The efficiency of solar cells depends on many factors such as temperature, irradiance, spectral characteristics of sunlight, dirt, shadow, and so on. Changes in insolation on panels due to fast climatic changes such as cloudy weather and increase in ambient temperature can reduce the photovoltaic (PV) array 
output power. In other words, each PV cell produces energy pertaining to its operational and environmental conditions [7].

In addressing the poor efficiency of PV systems, some methods were proposed, among which is a new concept called "maximum power point tracking" (MPPT). All MPPT methods follow the same goal which is maximizing the PV array output power by tracking the maximum power on every operating condition.

\section{SOLAR PHOTOVOLTAIC MODEL}

The mathematical model of the PV cell can be developed by using equivalent circuit model of PV Cell. An ideal solar cell may be modeled by a current source connected in parallel with a diode; the current source represents the generated photocurrent when the sunlight hits on the surface of the solar panel, and the diode represents the p-n transition area of the solar cell [8]. This PV cell model represents the electrical behavior of the pn-junction [9]-[11]. Figure 1 shows the single diode equivalent circuit model of Solar cell.

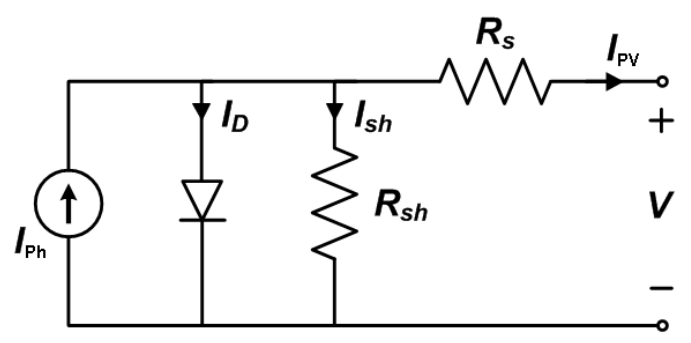

Figure 1. Solar Cell Equivalent Circuit Model

From the single diode equivalent circuit in Figure 1, the equation for the output current is given by:

$$
\mathrm{I}_{\mathrm{pv}}=\mathrm{I}_{\mathrm{ph}}-\mathrm{I}_{\mathrm{D}}-\mathrm{I}_{\mathrm{sh}}
$$

The current through the diode follow the Shockley diode equation:

$$
\begin{aligned}
& \mathrm{I}_{\mathrm{D}}=\mathrm{I}_{\mathrm{O}}\left[e^{\left(\frac{q V_{D}}{n k T}\right)}-1\right] \\
& \mathrm{I}_{\mathrm{sh}}=\frac{V_{\mathrm{sh}}}{\mathrm{R}_{\mathrm{sh}}} \\
& \mathrm{V}_{\mathrm{D}}=\mathrm{V}_{\mathrm{pv}}+\mathrm{I}_{\mathrm{pv}} \mathrm{R}_{\mathrm{s}}
\end{aligned}
$$

where, $I_{p v}$ is the PV output current, $I_{p h}$ is the photocurrent, $I_{D}$ is the diode current, $I_{s h}$ is the shunt current, $I_{O}$ is the reverse saturation current, $\mathrm{n}$ is diode ideality factor, $\mathrm{q}$ is the electron charge, $\mathrm{k}$ is the Boltzmann constant, $\mathrm{T}$ is the absolute temperature, $\mathrm{V}_{\mathrm{D}}$ is the voltage across diode and resistor $\mathrm{R}_{\mathrm{sh}}, \mathrm{V}_{\mathrm{pv}}$ is the output terminal voltage, and $R_{S}$ is the series resistance of the PV cells.

By substituting Equations (2), (3) and (4) into the first equation, the characteristic equation of a PV cell, which relates solar cell parameters to the output current and voltage, is given by the following expression[1], [2]:

$$
\mathrm{I}_{\mathrm{pv}}=\mathrm{I}_{\mathrm{ph}}-\mathrm{I}_{\mathrm{O}}\left[e^{\left(\frac{q\left(\mathrm{~V}_{\mathrm{pv}}+\mathrm{I}_{\mathrm{pv}} \mathrm{R}_{\mathrm{s}}\right)}{n k T}\right)}-1\right]-\frac{\mathrm{V}_{\mathrm{pv}}+\mathrm{I}_{\mathrm{pv}} \mathrm{R}_{\mathrm{s}}}{\mathrm{R}_{\mathrm{sh}}}
$$


The nonlinear equation of PV characteristic actualy depends on the solar irradiance and the cell temperature. As the references, the PV module manufacturers normally provided specified data at Standard Test Conditions where the irradiance is $1000 \mathrm{~W} / \mathrm{m}^{2}$ and the cell temperature is $25^{\circ} \mathrm{C}$.

In this paper, the ICA100 PV module was chosen for simulation setup. The electrical parameters are tabulated in Table 1, and the characteristic curves are shown in Figure 2 and Figure 3. Figure 2 illustrates the $\mathrm{P}-\mathrm{V}$ characteristic of the ICA100 module under different irradiance and Figure 3 illustrates the P-V characteristic under different temperature conditions.

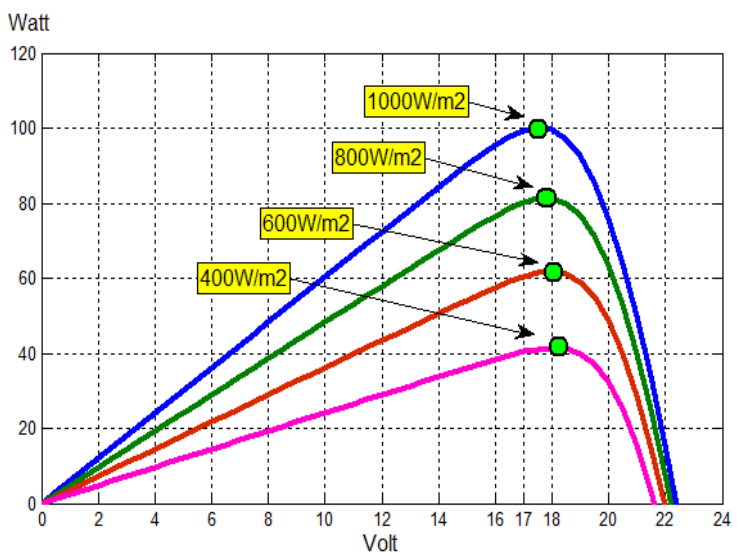

Figure 2. P-V characteristics at irradiance variation

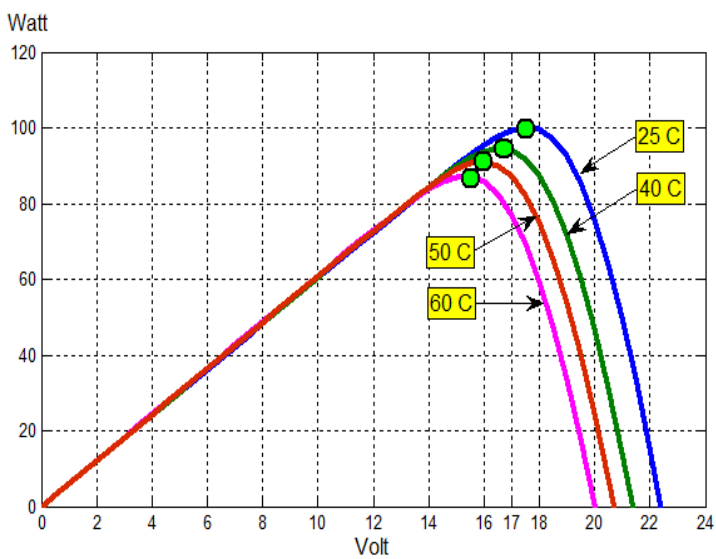

Figure 3. P-V characteristics at temperature variation

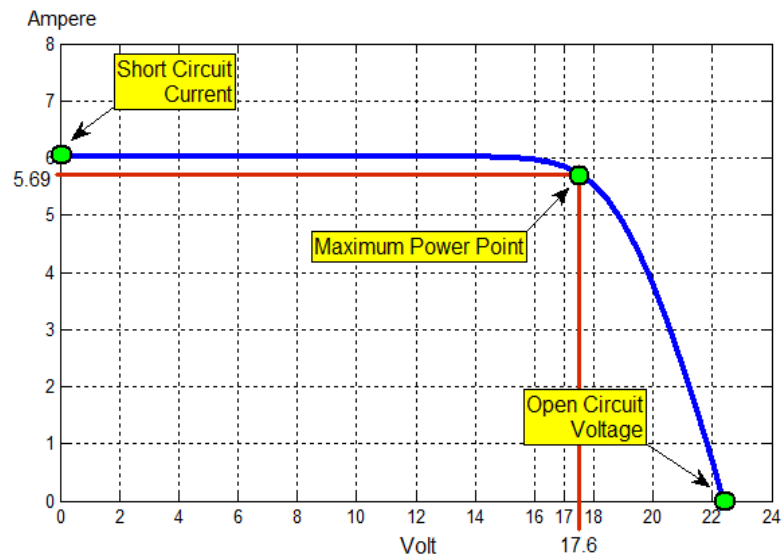

Figure 4. Current - vs - Voltage curve of PV module

Figure 4 shows the current-vs-voltage curve of the PV module. It gives an idea about the significant points on each I-V curve: open-circuit voltage, short-circuit current, and the operating point where the module performs the maximum power (MPP). This point is related to a voltage and a current that are Vmpp and Impp, respectively, and is highly dependent on solar irradiation and ambient temperature.

Table 1. Specification of ICA100 PV Module

\begin{tabular}{lll}
\hline \multicolumn{1}{c}{ Parameters } & \multicolumn{1}{c}{ Symbol } & \multicolumn{1}{c}{ Value } \\
\hline Maximum power & $\mathrm{P}_{\max }$ & $100 \mathrm{~W}$ \\
Voltage at max power & $\mathrm{V}_{\mathrm{mp}}$ & $17.6 \mathrm{~V}$ \\
Current at max power & $\mathrm{I}_{\mathrm{mp}}$ & $5.69 \mathrm{~A}$ \\
Open circuit voltage & $\mathrm{V}_{\mathrm{oc}}$ & $22.4 \mathrm{~V}$ \\
Short circuit current & $\mathrm{I}_{\mathrm{sc}}$ & $6.03 \mathrm{~A}$ \\
Number of Series Cells & $\mathrm{N}_{\mathrm{s}}$ & 36 \\
Number of Parallel Cells & $\mathrm{N}_{\mathrm{p}}$ & 1 \\
\hline
\end{tabular}




\section{MAXIMUM POWER POINT TRACKING (MPPT)}

The Maximum Power Point Tracking (MPPT) is an algorithm that included in charge controllers used for extracting maximum available power from PV module under certain conditions. The MPPT algorithm moves the electrical operating point of the PV modules to its Maximum Power Point, so that the modules are able to deliver maximum available power.

The voltage at which PV module can produce maximum power point is called maximum power voltage (or peak power voltage). The Maximum Power Point of PV module varies with solar radiation, ambient temperature and solar cell temperature. From Power - vs - Voltage curve in Figure 5, the ICA100 PV module produces power with maximum power voltage of around 17.6V when measured at a cell temperature of $25^{\circ} \mathrm{C}$, it can drop to around $16 \mathrm{~V}$ on a very hot day and it can also rise to $19 \mathrm{~V}$ on a very cold day.

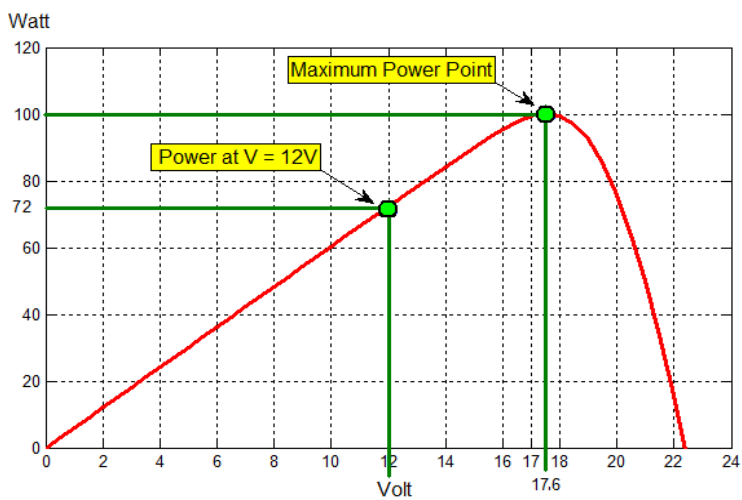

Figure 5. Power - vs - Voltage curve of PV module

When a load is directly connected to the PV panel, the PV panel operating point is usually not at peak power. In Figure 5, it is clear when a $12 \mathrm{~V}$ dc load is directly connected to the PV panel, the PV output power is only $72 \mathrm{~W}$, which is less then the maximum available power of PV module.

The impedance seen by the PV panel derives the electrical operating point of the solar PV panel. By varying the impedance seen by the PV panel, the electrical operating point can be moved towards peak power point. Since solar PV panels are DC devices, DC-DC converters might be used to transform the impedance of solar panel circuit to the load circuit. Changing the duty ratio of the DC-DC converter results in the impedance seen by the panel being changed. In order to maximize the extraction power of solar photovoltaic systems, the DC-DC converter must be able to track a particular duty ratio that make the operating point will be at the maximum power point (MPP).

There are a large number of algorithms that are able to track the MPPs. Some of them are simple, such as voltage and current feedback control base, while some are more complicated, such as hill cimbing method, Perturbation and Observation $(\mathrm{P} \& \mathrm{O})$ method and Incremental Conductance method. They vary in complexity, sensor requirement, speed of convergence, cost, range of operation, popularity, ability to detect multiple local maxima, and their applications [12]-[14].

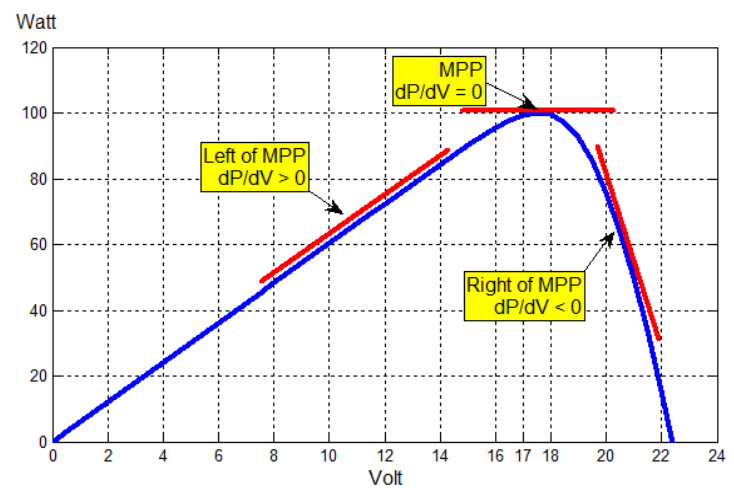

Figure 6. Basic idea of the MPPT method 
Most of MPPT method focuses directly on power variations and the slope of the $\mathrm{P}-\mathrm{V}$ characteristic curve. In Figure 6, we can see that the MPP is located at the peak of the Power - vs - Voltage curve of PV module. Here the value of PV power is maximum. Figure 6 shows that the slope of the PV array power curve, $\mathrm{dP} / \mathrm{dV}$, is zero at the MPP, positive on the left of the MPP and negative on the right-hand side of the MPP. The basic equations of this method are as follows :

$$
\begin{array}{ll}
\frac{d P}{d V}=0, & \text { at MPP } \\
\frac{d P}{d V}>0, & \text { left of MPP } \\
\frac{d P}{d V}<0, & \text { right of MPP }
\end{array}
$$

where $\mathrm{P}$ and $\mathrm{V}$ are the PV array output power and voltage, respectively.

\section{MPPT FUZZY LOGIC CONTROLLER}

Fuzzy Logic has been used for tracking the Maximum Power Point (MPP) of PV module because it has the advantages of being robust, relatively simple to design and does not require the knowledge of PV exact model. Fuzzy logic control generally consists of three basic componens: fuzzification module, fuzzy inference engine, and defuzzification module, as shown in Figure 7.

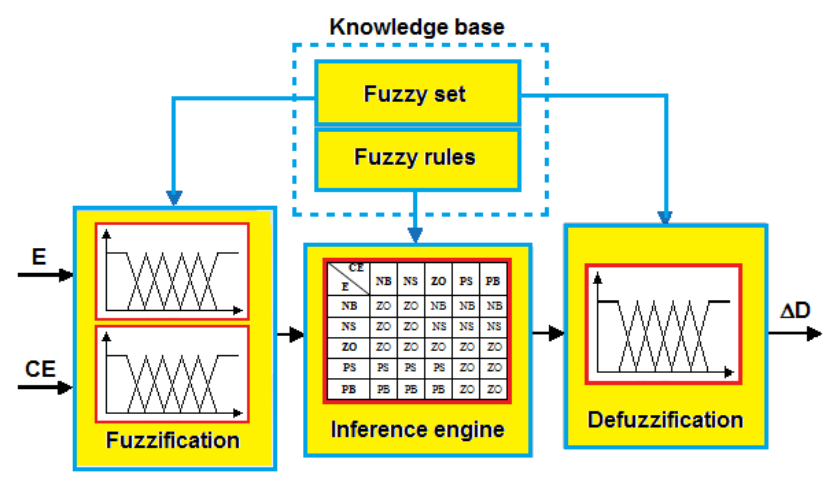

Figure 7. Structure of fuzzy logic controller

\subsection{Fuzzification}

During fuzzification, numerical input variables are converted into linguistic variable based on a membership function. For this MPPT, the actual voltage and current of PV module measured continuously and the power can be calculated as $\mathrm{P}=\mathrm{VxI}$. The control is determined based on satisfaction of two proposed input control variable, namely the error $\mathrm{E}$ (which represents the slope of $\mathrm{P}-\mathrm{V}$ characteristic) and change of error $\mathrm{CE}$ at the instant sampling $\mathrm{k}$. The variable $\mathrm{E}$ and $\mathrm{CE}$ are exprexed as follows:

$$
\begin{aligned}
& E(k)=\frac{P(k)-P(k-1)}{V(k)-V(k-1)} \\
& C E(k)=E(k)-E(k-1)
\end{aligned}
$$

where $\mathrm{P}(\mathrm{k})$ is the power and $\mathrm{V}(\mathrm{k})$ is voltage of $\mathrm{PV}$ module. The change in duty ratio $(\Delta \mathrm{D})$ of the DC-DC Converter is used as the output of the controller. Therefore, the control is done by changing this duty ratio according to the slope $\mathrm{E}(\mathrm{k})$ in order to track the operation point to the optimal point where the slope is zero.

Modeling and Simulation of Fuzzy Logic based Maximum Power Point ... (Ahmad Saudi Samosir) 
As shown in Figure 8, the input variables of the fuzzy controller (E, CE) are converted to the liguistic variables such as PB (positive big), PS (positive small), ZO (zero), NS (negative small), and NB (negative big) using basic fuzzy subset. Figure 8 shows the membership grades of five basic fuzzy subsets for input and output variables.

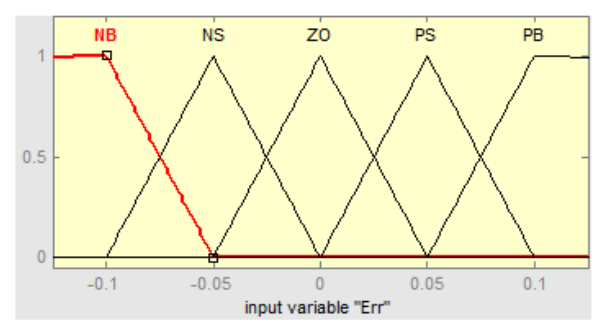

(a)

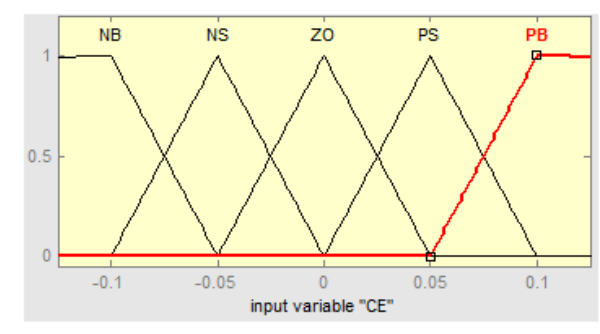

(b)

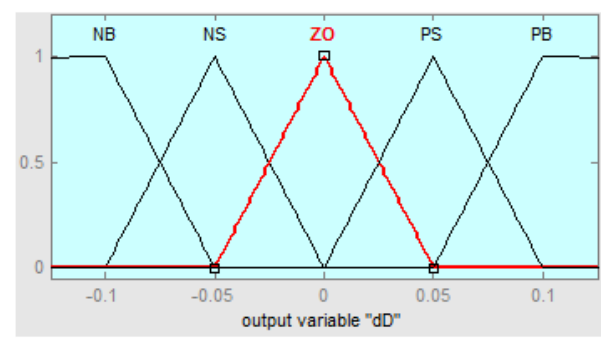

(c)

Figure 8. Membership function for (a) Input E, (b) Input CE, (c) Output $\Delta \mathrm{D}$

\subsection{Inference engine}

The inference engine applies a rule to the fuzzy input to determine the fuzzy output. Therefore, before the rule can be evaluated, the real input value must be fuzzified to obtain an appropriate linguistic value. Table 2 shows the fuzzy controller rule table, where all the matrix entries are fuzzy sets of the error $(E)$, the change of error $(C E)$ and the change of duty ratio $(\Delta D)$ to converter.

The rule table in Table 2 containt 25 rules of fuzzy controller. These rules are employed to control the DC-DC converter so that the MPP of the PV module is reached. The main idea of the rules are to bring the operation point of PV module to the MPP by increasing or decreasing the duty ratio of DC-DC Converter depending on the position of the operation point from the MPP.

\subsection{Defuzzification}

Since the DC-DC converter require a precise control signal D at its entry, it is necessary to tranform the output of fuzzy controller from fuzzy information into deterministic information. This tranformation is called defuzzification. In the defuzzification stage, the fuzzy logic controller output is converted from a linguistic variable to a numerical variable.

Defuzzification can be performed normally by two algorithms; Center of Area (COA) and the Max Criterion Method (MCM). The most widely used defuzzification method is the determination of the center of gravity (COA) of the final combined fuzzy set.

The final combined fuzzy set is defined by the unification of all outputs of the fuzzy rule set, using the maximum aggregation method. The center of gravity $(\Delta \mathrm{D})$ is computed by,

$$
\Delta D=\frac{\sum_{j=1}^{n} \mu\left(\Delta D_{j}\right) \square \Delta D_{j}}{\sum_{j=1}^{n} \mu\left(\Delta D_{j}\right)}
$$


and the actual duty ratio $\mathrm{D}$ is calculated by:

$$
D(k)=D(k-1)+S_{\Delta D} \sqcap \Delta D(k)
$$

\section{RESULT AND ANALYSIS}

In order to evaluate the performance of the proposed Fuzzy Logic based MPPT controller, a simulation analysis was conducted. The simulation model was developed using MATLAB Simulink. The simulink model of PV system is shown as Figure 9. The PV module considered in the simulation is the ICA100.

Figure 9 shows the developed PV model system consisting of PV Solar Panel, Power Circuit and MPPT controller block diagram which is implemented using Fuzzy logic controller. The Fuzzy MPPT algorithm is presented in Figure 10. Figure 11 shows the simulation result of the Fuzzy MPPT algorithm response.

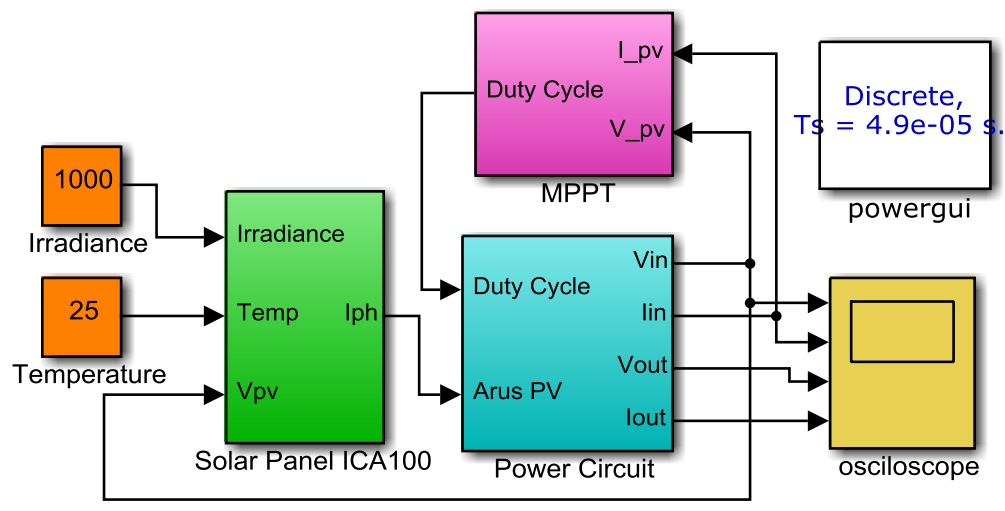

Figure 9. Simulink model of PV system

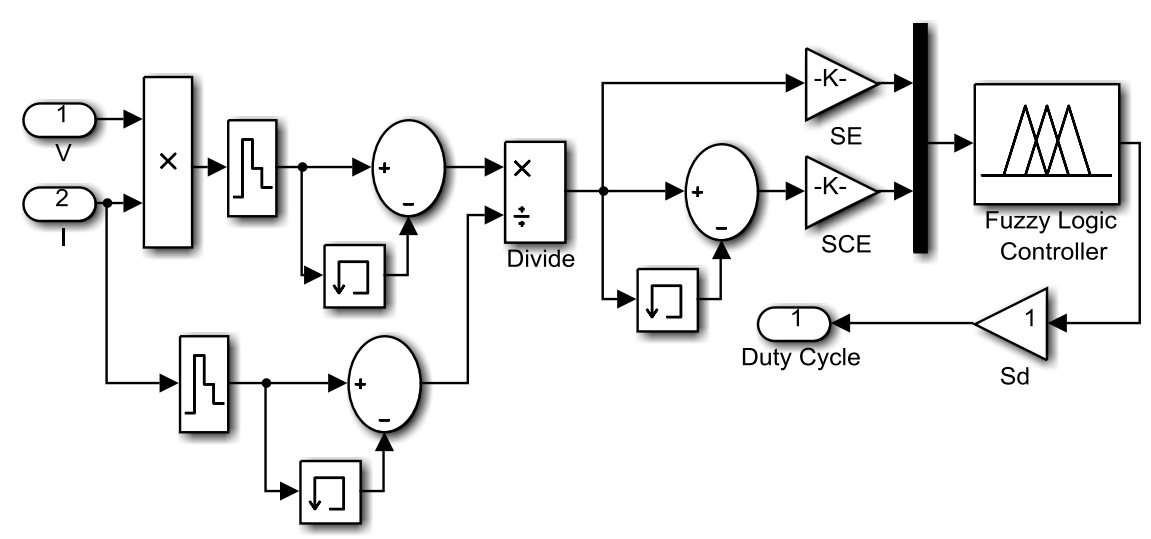

Figure 10. Block diagram of fuzzy MPPT algorithm 

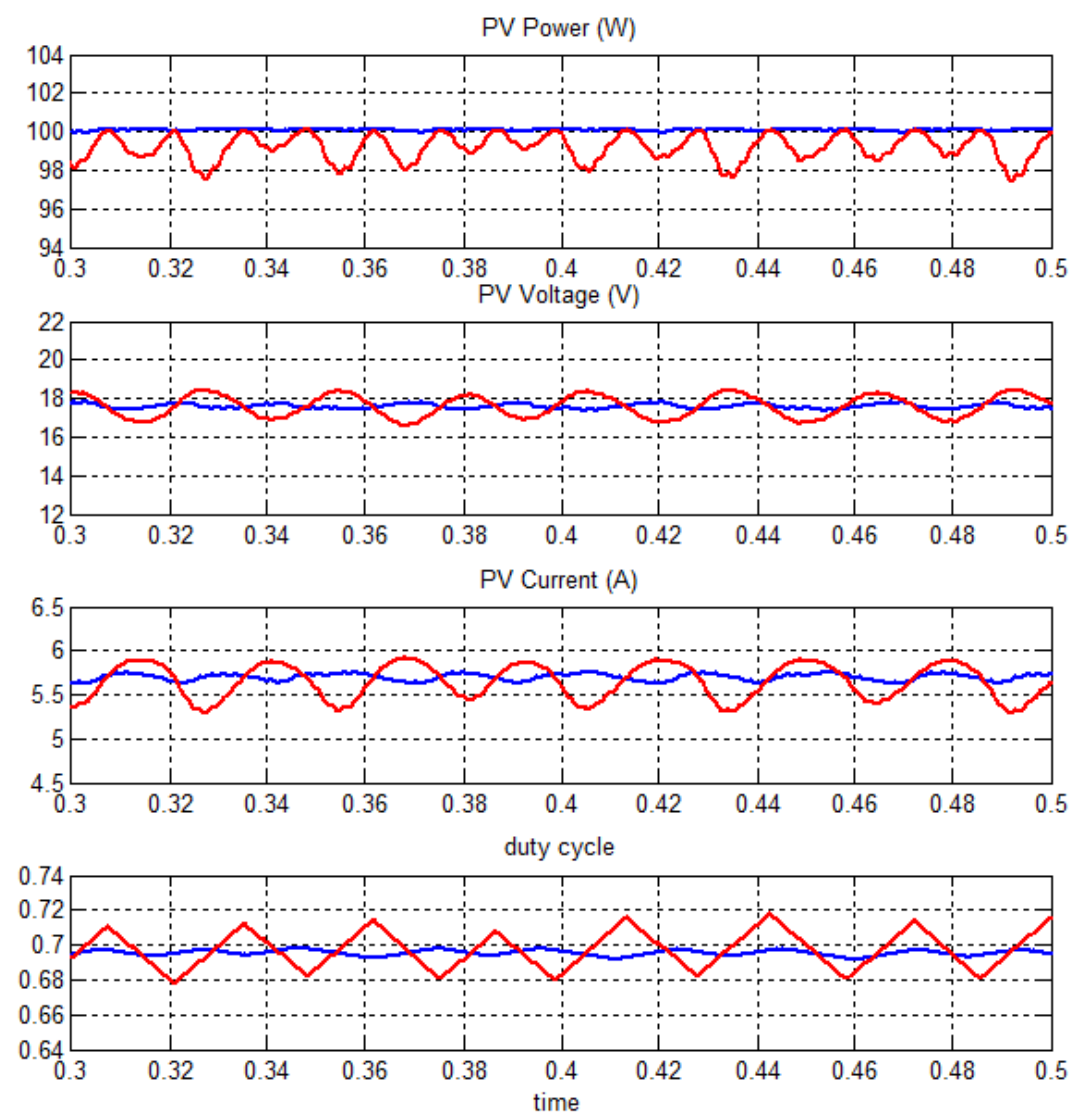

Figure 11. fuzzy MPPT algorithm response

\section{CONCLUSION}

A modeling and simulation of fuzzy logic based Maximum Power Point Tracking for PV application is presented. The performance of the fuzzy logic MPPT algorithm system has been investigated. The simulation results show that the proposed fuzzy logic algorithm has a good and effective performance to generate maximum power from solar panels.

\section{ACKNOWLEDGEMENTS}

The authors would like to thanks the Directorate General of Higher Education Indonesia (DIKTI) for the financial support, and Lampung University for providing the facilities to conduct the research.

\section{REFERENCES}

[1] Azadeh Safari and Saad Mekhilef, "Simulation and Hardware Implementation of Incremental Conductance MPPT with Direct Control Method Using Cuk Converter", IEEE Transactions on Industrial Electronics, vol. 58, no. 4, April 2011.

[2] M. Abdulkadir, A.S. Samosir and A.H.M. Yatim, "Modelling and simulation of maximum power point tracking of photovoltaic system in Simulink model”, PECon 2012 - IEEE International Conference on Power and Energy, 2012.

[3] M. Abdulkadir, A.S. Samosir and A.H.M. Yatim, "Modeling and Simulation of a Solar Photovoltaic System, Its Dynamics and Transient Characteristics in LABVIEW", ARPN Journal of Engineering and Applied Sciences, vol. 3, no. 2, Jun 2013.

[4] A. S. Samosir, A. Trisanto, A. Sadnowo, "Development of dynamic evolution control for pv inverter in solar power plant application", ARPN Journal of Engineering and Applied Sciences, vol. 12, no.12, Jun 2017.

[5] M. A. Abdourraziq and M. Maaroufi, "Experimental Verification of the Main MPPT Techniques for Photovoltaic System", International Journal of Power Electronics and Drive Systems (IJPEDS), vol. 8, no. 1, pp. 384-391, March 2017. 
[6] Z. Almukhtar, A. Merabet, "Fuzzy MPPT Control and Power Regulation for Standalone Photovoltaic Energy Conversion System", International Journal of Advanced Engineering Research and Applications (IJA-ERA), vol. 2, no. 7, Nov 2016.

[7] F. Liu, S. Duan, F. Liu, B. Liu, and Y. Kang, "A variable step size INC MPPT method for PV systems," IEEE Trans. Ind. Electron, vol. 55, no. 7, pp. 2622-2628, Jul. 2008.

[8] N. Mohammad, M. A. Islam, T. Karim, and Q. D. Hossain, "Improved Solar Photovoltaic Array Model with FLC Based Maximum Power Point Tracking", International Journal of Electrical and Computer Engineering (IJECE), vol. 2, no. 6, pp. 717-730, December 2012.

[9] Pandiarajan, N, Ranganath Muthu, "Mathematical Modeling of Photovoltaic Module with Simulink", International Conference on Electrical Energy System, ICESS 2011.

[10] H. Gusmedi, E. Komalasari, "DocumentFeasibility and optimal design of micro-hydro and photovoltaic hybrid system in support to energy independent village", Proceedings - ICPERE 2014: 2nd IEEE Conference on Power Engineering and Renewable Energy, 2014.

[11] Amirullah and A. Kiswantono, "Power Quality Enhancement of Integration Photovoltaic Generator to Grid under Variable Solar Irradiance Level using MPPT-Fuzzy", International Journal of Electrical and Computer Engineering (IJECE), vol. 6, no. 6, pp. 2629-2642, December 2016.

[12] T. Esram and P. L. C hapman, "Comparison of photovoltaic array maximum power point tracking techniques," IEEE Trans. Energy Conversion, vo 1. 22, no. 2, pp. 439-449, Jun. 2007.

[13] V. Salas, E. Olias, A. B arrado, and A. Lazaro, "Review of the maximum power point tracking algorithms for standalone photovoltaic systems," Solar Energy Materials and Solar Cells, vol. 90, no. 11, pp. 1555-1578, Jul. 2006.

[14] M.A. Abdullah, A.H.M.Yatim, C.W. Tan, A.S. Samosir, "Particle swarm optimization-based maximum power point tracking algorithm for wind energy conversion system", PECon 2012 - IEEE International Conference on Power and Energy, 2012.

\section{BIOGRAPHIES OF AUTHORS}

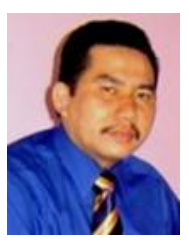

Ahmad Saudi Samosir was born in Belawan, Indonesia in 1971. He obtained his Bachelor degree in electrical engineering from University of North Sumatera, Indonesia, in 1995, Master degree in electrical power engineering from Bandung Institute of Technology, Indonesia, in 1999, and $\mathrm{PhD}$ degree from Universiti Teknologi Malaysia, Malaysia, in 2010. His areas of interest research include renewable energy, control technique and application of power electronic converters. Currently he is working as a professor in the department of Electrical Engineering, University of Lampung, Bandar Lampung, Indonesia.

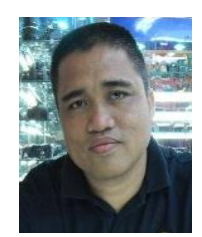

Herri Gusmedi was born in Palembang, Indonesia in 1971. He received his Bachelor degree in electrical engineering from Sriwijaya University, Indonesia, in 1995, and Master degree in electrical power engineering from Bandung Institute of Technology, Indonesia, in 2001. His research area includes power system, load analysis, system monitoring and renewable energy. Currently $\mathrm{He}$ is working as a lecturer in the department of Electrical Engineering, University of Lampung, Bandar Lampung, Indonesia.

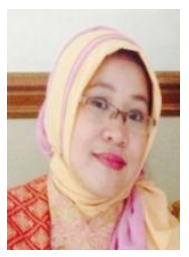

Sri Purwiyanti was born in Jakarta, Indonesia in 1973. She received bachelor degree in electrical engineering from Universitas Mercubuana, Indonesia, in 1996, Master degree in electrical engineering from Universitas Gajah Mada, Indonesia, in 2000, and $\mathrm{PhD}$ degree from Universitas Indonesia and Shizuoka University, Japan, in 2015. Her research interest includes electronic system, nanowire silicon semiconductor, application of artificial intelligent in power system as well as renewable energy in distributed generation. Currently She is working as a lecturer in the department of Electrical Engineering, University of Lampung, Bandar Lampung, Indonesia.

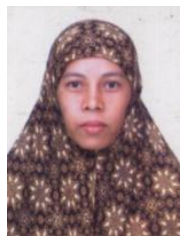

Endah Komalasari was born in Ujung Pandang, Indonesia in 1973. She received bachelor degree in electrical engineering from Sriwijaya University, Indonesia, in 1997, Master degree in electrical power engineering from Bandung Institute of Technology, Indonesia, in 2002, and $\mathrm{PhD}$ degree from Kyushu University, Japan, in 2012. Her research interest includes system monitoring, power electronic system, and renewable energy. Currently She is working as a lecturer in the department of Electrical Engineering, University of Lampung, Bandar Lampung, Indonesia. 